\title{
PENGEMBANGAN PEMBELAJARAN BERBASIS RISET DI JURUSAN TADRIS BAHASA INDONESIA FITK, IAIN SYEKH NURJATI CIREBON
}

\author{
Indrya Mulyaningsih, Moh. Ali Zahidin, Nina Nurfiana \\ IAIN Syekh Nurjati Cirebon \\ indrya_m@yahoo.com
}

\begin{abstract}
Abstrak
Penelitian ini bertujuan untuk: (1) mendeskripsikan pembelajaran, (2) mendeskripsikan model pembelajaran berbasis riset, dan (3) mendeskripsikan pendapat mahasiswa terhadap model pembelajaran yang digunakan di Jurusan Tadris Bahasa Indonesia. Penelitian ini berbentuk deskriptif eksplanatif. Adapun data penelitian berupa 11 mata kuliah pada Semester Genap Tahun Akademik 2015/2016. Data dikumpulkan dengan tiga (3) cara, yakni observasi, wawancara, dan analisis dokumen. Validitas data menggunakan teknik triangulasi, baik sumber data maupun metode pengumpulan data. Data dianalisis dengan menggunakan analisis interaktif. Hasil penelitian menunjukkan bahwa 1) secara umum, pembelajaran di Jurusan Tadris Bahasa Indonesia menggunakan ceramah dan diskusi; 2) hanya satu mata kuliah yang menggunakan model pembelajaran berbasis riset; 3) mahasiswa beranggapan bahwa model pembelajaran yang digunakan di Jurusan Tadris Bahasa Indonesia IAIN Syekh Nurjati kurang variatif.
\end{abstract}

Kata kunci: bahasa, Indonesia, model, pembelajaran, riset

\begin{abstract}
This study aims to: (1) describe the learning, (2) describe the research-based learning model, and (3) describe the opinion of students to the learning model used in the Indonesian Education Department. This study was a descriptive explanation. The research data on 11 subjects Semester, Academic Year 2015/2016. Data collected by three (3) different ways, including observation, interviews and document analysis. The validity of the data using triangulation techniques, both data sources and data collection methods. Data were analyzed using interactive analysis. These research results show that 1) in general, learning at the Indonesian Education Department using lecture and discussion; 2) only one course that uses research-based learning model; 3) students thought that learning model used in the Indonesian Education Department, IAIN Syekh Nurjati less varied.
\end{abstract}

Keywords: language, Indonesia, model, learning, research

\section{A. Pendahuluan}

Jurusan Tadris Bahasa Indonesia memiliki tugas utama, yakni pada kemampuan menghasilkan para pendidik yang profesional dengan memegang teguh nilai-nilai Islam dan Indonesia. Saat ini, keberadaan bahasa asing sudah sangat luas dan bebas di Negara 
ini. Para orang tua lebih bangga jika putra-putri mereka pandai dan mahir berbahasa asing. Fenomena ini tentu saja akan menggeser keberadaan bahasa Indonesia. Walaupun tidak hilang, tetapi pengetahuan dan kepiawaian dalam berbahasa Indonesia akan menurun.

Keberadaan Tadris Bahasa Indonesia sangat penting untuk menjawab fenomena di atas. Tadris Bahasa Indonesia diharapkan dapat menjaga dan mengembangkan keberadaan bahasa Indonesia itu sendiri. Oleh karena itu, mahasiswa Jurusan Tadris Bahasa Indonesia tidak hanya menguasai materi, tetapi juga dapat menggunakannya sesuai kaidah. Selain itu, mahasiswa Tadris Bahasa Indonesia juga harus dapat mengajarkan Bahasa Indonesia itu sendiri.

Demi mencapai tujuan tersebut, hendaknya pembelajaran dilaksanakan secara efektif dan efisien. Salah satu faktor yang mempengaruhi keberhasilan dalam pembelajaran adalah modelnya. Model pembelajaran merupakan salah satu faktor yang turut menentukan keberhasilan mahasiswa dalam belajar. Selama ini telah dikenal beragam model pembelajaran. Salah satunya adalah pembelajaran berbasis riset. Begitu banyak pemahaman tentang pembelajaran berbasis riset. Setiap ilmu pengetahuan memiliki ciri khusus. Maka dari itu, dalam penerapannya pun memerlukan cara tersendiri. Melalui penelitian ini diharapkan dapat ditemukan model pembelajaran berbasis riset yang sesuai dengan Jurusan Tadris Bahasa Indonesia.

Pembelajaran bahasa merupakan proses mempelajari bahasa. Konsep dasar bahasa yang dipelajari, yakni fonologi, morfologi, sintaksis, dan semantik. Fonologi adalah "deskripsi sistem dan pola bunyi ujaran dalam sebuah bahasa" (Yule, 2014: 60). Morfologi diartikan sebagai studi tentang bentuk bahasa. Ilmu morfologi menyangkut struktur internal kata (Verhaar, 2012: 11). Sintaksis merupakan "salah satu cabang tata bahasa yang menelaah struktur-struktur kalimat, klausa, dan frasa" (Tarigan, 2009: 4). Semantik merupakan studi ilmiah tentang makna (Pateda, 2010: 25). Suwandi (2008: 9) menyatakan bahwa semantik merupakan telaah lambang atau tanda yang menyatakan makna, hubungan makna yang satu dengan makna yang lain dan pengaruhnya terhadap manusia dan masyarakat.

Model pembelajaran berfungsi sebagai pedoman bagi pengajar dalam merencanakan dan melaksanakan pembelajaran dari awal sampai akhir (Mulyatingsih, 2010: 1). Oleh karena itu, metode pembelajaran memuat pendekatan, metode, dan 
teknik pembelajaran. Sukmadinata dan Erliana (2012: 151) menambahkan adanya penciptaan situasi lingkungan yang memungkinkan pembelajar untuk belajar. Supriadie dan Darmawan (2012: 9) yang menambahkan bahwa "pembelajaran adalah suatu konsepsi dari dua dimensi kegiatan belajar dan mengajar”. Prinsip belajar haruslah berorientasi pada pembelajar. Menurut pendekatan Feuerstein (dalam Bellanca, 2011: 6) keberhasilan dalam belajar dapat dicapai melalui (a) mengubah siswa untuk belajar lebih efisien dan (b) mengajar untuk menggali potensi yang dimiliki pembelajar. Model belajar atau model pembelajaran harus disesuaikan dengan kondisi peserta didik. Joyce, Marsha, dan Emily (2011: 1) menyatakan bahwa kunci utama untuk mencapai tujuan pembelajaran adalah dengan menggunakan model pembelajaran efektif yang berorientasi pada kecerdasan. Oleh karena itu, model pembelajaran yang dipilih hendaknya mampu melatih pembelajar untuk menjadi lebih handal.

Selain itu, pengajar juga dapat menyusun atau merencanakan model pembelajaran sendiri. Adapun hal yang perlu diperhatikan menurut Wahyuni dan Abdul (2012: 14), meliputi: kemampuan analitik, kemampuan pengembangan, dan kemampuan pengukuran. Kemampuan analitik berupa analisis terhadap kondisi pembelajaran. Kualitas pembelajaran ditentukan oleh teknik yang mengarah pada langkah-langkah dalam pembelajaran (Henard dan Deborah, 2012: 7). Kualitas pembelajaran, meliputi beberapa hal, seperti 1) disain dan materi kurikulum yang tepat, 2) keberagaman metode pembelajaran, 3) penggunaan umpan balik, dan 4) penilaian hasil belajar yang efektif.

Pembelajaran di perguruan tinggi tentu saja memiliki karakter yang berbeda dengan di sekolah, baik dasar, menengah, maupun atas. Pembelajaran di perguruan tinggi dapat dikategorikan dengan pembelajaran orang dewasa. Salah satu yang dapat digunakan adalah pembelajaran berbasis riset (PBR). PBR merupakan metode pembelajaran yang menggunakan authentic learning, problem-solving, cooperative learning, contextual (hands on \& minds on, dan inquiry discovery approach yang dipandu oleh filosofi konstruktivisme (Widayati dkk, 2010: 4).

Terdapat beberapa strategi dalam memadukan pembelajaran dan riset, yaitu; (1) memperkaya bahan ajar dengan hasil penelitian dosen, (2) menggunakan temuantemuan penelitian mutakhir dan melacak sejarah, (3) memperkaya kegiatan pembelajaran dengan isu-isu penelitian kontemporer, (4) mengajarkan materi metodologi penelitian di dalam proses pembelajaran, (5) memperkaya proses 
pembelajaran dengan kegiatan penelitian dalam skala kecil, (6) memperkaya proses pembelajaran dengan melibatkan peserta didik dalam kegiatan, (7) memperkaya proses pembelajaran dengan mendorong peserta didik, dan (8) memperkaya proses pembelajaran dengan nilai-nilai yang harus dimiliki oleh peneliti (Umar dkk, 2011: 22).

\section{B. Metode Penelitian}

Penelitian ini berbentuk deskriptif eksplanatif. Hal ini karena data yang dikumpulkan berupa kata-kata, gambar, dan bukan angka-angka (Moleong, 2010:11). Data dikumpulkan dengan cara observasi, wawancara, dan analisis dokumen (Cohen, 2000: 271; Moleong, 2010: 9). Validitas data pada penelitian tahap ini ditempuh dengan triangulasi sumber, triangulasi metode, triangulasi peneliti, dan triangulasi teori (Moleong, 2000: 178; 2010: 330). Penelitian ini dilakukan selama empat bulan, dari Februari-Juni 2016.

\section{Hasil dan Pembahasan}

Jurusan TBI IAIN Syekh Nurjati Cirebon merupakan jurusan yang baru berdiri, tepatnya Mei 2015. Oleh karena itu, data pada penelitian ini adalah seluruh mata kuliah pada Semester Genap Tahun Akademik 2015/2016, yakni satu kelas dengan 11 mata kuliah, meliputi: 1) Akhlak Tasawuf, 2) Linguistik Umum, 3) Berbicara, 4) Bimbingan dan Konseling, 5) Filsafat Bahasa, 6) Fonologi Bahasa Indonesia, 7) Membaca, 8) Menulis, 9) Menyimak, 10) Pancasila, dan 11) Teori Belajar Bahasa.

Ke-11 mata kuliah tersebut dapat dikelompokkan menjadi dua, yakni mata kuliah teori dan mata kuliah praktik. Mata kuliah disebut mata kuliah teori karena pembelajaran ini bertujuan pada pengenalan dan lebih banyak pada pemahaman terhadap berbagai teori. Demikian sebaliknya, mata kuliah disebut mata kuliah praktik karena pembelajaran ini bertujuan mempraktikkan bahkan menghasilkan sehingga mahasiswa memiliki keterampilan. Mata kuliah teori terdiri atas: 1) Akhlak Tasawuf, 2) Linguistik Umum, 3) Filsafat Bahasa, 4) Fonologi Bahasa Indonesia, 5) Pancasila, dan

6) Teori Belajar Bahasa. Adapun mata kuliah praktik mencakup: 1) Bimbingan dan Konseling, 2) Berbicara, 3) Membaca, 4) Menulis, dan 5) Berbicara.

Sepanjang pengamatan dapat disimpulkan bahwa pembelajaran mata kuliah pada Semester Genap Tahun Ajaran 2015/2016 lebih banyak menggunakan penugasan. 


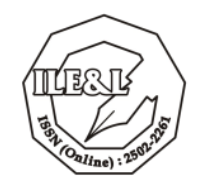

Journal Indonesian Language Education and Literature Vol. 2, No. 2, 2017

http://www.syekhnurjati.ac.id/jurnal/index.php/jeill/

Dosen membagi kelas menjadi beberapa kelompok. Setiap kelompok diminta untuk membuat makalah dan dipresentasikan. Adapun tema makalah ditentukan oleh dosen. Biasanya tema disesuaikan dengan materi yang akan dibahas pada setiap pertemuan. Kelompok yang pertama kali presentasi merupakan kelompok yang mendapat tema atau materi pertama, sesuai urutan Rencana Pembelajaran Semester (RPS) mata kuliah yang bersangkutan. Berikut ini hasil analisis per mata kuliah.

Bimbingan Konseling. Mata kuliah ini memiliki tujuan agar mahasiswa dapat mempraktikkan dalam memberi bimbingan dan konseling pada siswa. Metode pembelajaran dilakukan dengan menyampaikan teori dan mempraktikkan teori tersebut. Teori disampaikan dengan metode ceramah, yakni dosen menyampaikan materi. Selain itu, materi juga diberikan melalui penugasan. Mahasiswa diminta membuat makalah. Makalah ini berisi materi yang telah ditetapkan oleh dosen. Makalah ini bersifat informasi. Artinya, materi yang ada tidak berupa penyelesaian suatu masalah, tetapi lebih pada informasi.

Menulis. Mata kuliah ini bertujuan agar mahasiswa memiliki kemampuan dan keterampilan dalam menulis. Pembelajaran yang dilakukan dengan cara memberi tugas kepada mahasiswa untuk membuat tulisan. Tulisan tersebut kemudian dianalisis sesuai syarat sebuah tulisan yang baik. Selanjutnya mahasiswa diminta untuk memperbaiki tulisan tersebut sesuai hasil analisis. Mata kuliah ini merupakan mata kuliah prasyarat untuk mengikuti mata kuliah menulis lanjut. Oleh karena itu, mahasiswa diharapkan benar-benar memiliki pengetahuan tentang menulis dan mempraktikkannya. Mahasiswa diharapkan mampu menghasilkan tulisan dan mempublikasikannya, baik di media massa cetak maupun online.

Fonologi Bahasa Indonesia. Fonologi merupakan mata kuliah penciri jurusan. Secara umum, mata kuliah ini merupakan mata kuliah teori. Tujuan pembelajaran ini adalah agar mahasiswa mengetahui dasar-dasar fonologi dalam bahasa Indonesia. Fonologi itu sendiri merupakan ilmu yang berbicara tentang lafal atau bunyi. Secara spesifik, fonologi mempelajari fonetik, fonemik, segmental, dan suprasegmental. Model pembelajaran yang digunakan adalah perpaduan antara ceramah dengan diskusi. Ceramah dilakukan ketika dosen menyampaikan teori. Hal ini hanya dilakukan sekali waktu karena mahasiswa juga ditugasi untuk berdiskusi. Diskusi yang dimaksud adalah mempresentasikan makalah. Maksudnya, mahasiswa dibagi dalam beberapa kelompok. 
Setiap kelompok diwajibkan membuat makalah dengan tema yang telah ditentukan oleh dosen. Setiap pertemuan terdapat satu kelompok yang mempresentasikan makalah. Selesai presentasi, mahasiswa lain diperolehkan untuk mengajukan pertanyaan maupun sanggahan.

Linguistik Umum. Linguistik umum merupakan mata kulilah penciri jurusan. Tujuan mata kuliah ini adalah agar mahasiswa memiliki pengetahuan dasar mengenai linguistik. Pengetahuan tersebut mencakup konsep bahasa, hakikat, fungsi bahasa, linguistik sebagai ilmu, objek kajian linguistik, cabang linguistik, dan beberapa aliran dalam linguistik. Berdasarkan hal tersebut maka dapat diketahui bahwa mata kuliah ini bersifat umum dan lebih pada penguasaan pengetahuan. Pengetahuan dapat dimaknai dengan teori. Artinya, mahasiswa lebih diprioritaskan pada penguasaan teori. Pembelajaran ini menggunakan metode penugasan dan diskusi. Penugasan yang dimaksud adalah dosen membagi kelas menjadi beberapa kelompok. Setiap kelompok diminta untuk membuat makalah. Tema makalah ditentukan oleh dosen. Pada satu pertemuan, terdapat satu kelompok yang mempresentasikan makalah. Selesai presentasi, mahasiswa lain diberi waktu untuk memberi tanggapan, baik pernyataan maupun pertanyaan. Kelompok yang presentasi disilakan untuk menjawab dan menanggapi. Di akhir diskusi, dosen akan menyimpulkan dan membantu menjawab pertanyaan yang belum dijawab oleh kelompok.

Pancasila. Pancasila merupakan mata kuliah nasional. Artinya, setiap mahasiswa harus menempuh mata kuliah ini. Berdasarkan RPS, Pancasila adalah mata kuliah yang bertujuan untuk membentuk karakter dan memberi bekal. Hal ini menunjukkan bahwa Pancasila merupakan mata kuliah teori. Adapun pembelajaran yng dilakukan menggunakan dua metode, yakni ceramah dan diskusi. Seperti halnya mata kuliah lain, Pancasila juga meminta mahasiswa untuk membuat makalah lalu mempresentasikan. Materi makalah sudah ditentukan oleh dosen. Sekali waktu, dosen akan menggunakan satu pertemuan penuh untuk menyampaikan materi. Jika memang terdapat hal-hal yang belum dimengerti, mahasiswa diperbolehkan untuk mengajukan pertanyaan. Sedangkan sesi diskusi, setiap kelompok dipersilakan untuk mempresentasikan makalah yang telah dibuat. Sesi dilanjutkan dengan tanya jawab. Dalam satu sesi diberikan tiga mahasiswa untuk bertanya. Setiap pertemuan, hanya satu kelompok yang presentasi. Oleh karena 
itu, sesi pertanyaan dapat dibagi menjadi dua sehingga total penanya dapat mencapai antara 6 sampai 8 mahasiswa.

Menyimak. Menyimak merupakan mata kuliah penciri jurusan. Mata kuliah ini memberi mahasiswa salah satu keterampilan berbahasa. Menyimak merupaka hal mendasar yang harus dimiliki oleh setiap individu. Oleh karena itu, mahasiswa jurusan bahasa Indonesia sangat perlu dibekali kemampuan ini. Dalam RPS juga termaktub bahwa melalui mata kuliah ini, mahasiswa diharapkan memiliki kemampuan menyimak yang baik. Pembelajaran yang dilakukan lebih banyak pada praktik. Pada dasarnya, praktik menyimak dapat dilakukan di luar maupun di laboratorium (lab). Karena Jurusan belum memiliki lab, maka mahasiswa sering praktik menyimak di kelas saja. Sebelum praktik, mahasiswa juga harus memiliki bekal teori, walaupun sedikit. Teori yang dimiliki mahasiswa berasal dari penugasan yang diberikan oleh dosen.

Berbicara. Berbicara merupakan salah satu mata kuliah keterampilan berbahasa. Sebagai kemampuan berbahasa yang bersifat produktif, berbicara memerlukan teknik dan keahlian tertentu. Sebagai mata kuliah penciri jurusan, berbicara memang dapat dikelompokkan sebagai mata kuliah keterampilan. Hal ini juga tercantum pada RPS. Seperti halnya mata kuliah lain, meskipun berbicara merupakan mata kuliah keterampilan, tetapi mahasiswa tetap harus belajar teori. Teori tersebut terutama adalah teori dasar. Oleh karena itu, pembelajaran yang dilakukan juga berupa penyampaian materi baru kemudian praktik. Teori tentang berbicara disampaikan dosen pada awalawal pertemuan, yakni pertemuan pertama dan kedua. Selanjutnya, doaen membagi mahasiswa menjadi beberapa kelompok. Setiap kelompok diminta untuk membuat makalah. Tema makalah ditentukan berdasarkan materi yang telah ditetapkan oleh dosen.

Akhlak Tasawuf. Mata kuliah ini adalah penciri IAIN. Maksudnya, Akhlak Tasawuf merupakan mata kuliah yang dititipkan oleh Institut. Mata kuliah ini tidak terdapat pada perguruan tinggi lain. Oleh karena itu, mata kuliah ini dapat dikatakan sebagai mata kuliah penciri institut. Berdasarkan RPS, mata kuliah ini merupakan mata kuliah teori. Artinya, materi-materi yang disampaikan lebih banyak berupa materi. Pembelajaran yang dilakukan tidak jauh berbeda dengan mata kuliah lain. Dosen membagi kelas menjadi beberapa kelompok. Setiap kelompok terdiri atas $5-6$ mahasiswa. Setiap kelompok membuat makalah dengan tema yang telah ditentukan oleh 
dosen. Setiap pertemuan terdapat satu kelompok yang mempresentasikan makalah yang sudah disusun. Setelah presentasi akan ada sesi tanya jawab. Hal ini berlangsung sampai waktu pembelajaran akan habis. Setelah dirasa cukup, presentasi ditutup. Selanjutnya, dosen akan menjelaskan kembali berbagai pertanyaan yang telah diajukan. Dosen mencoba mengulas dan menyimpulkan.

Filsafat Bahasa. Filsafat bahasa merupakan salah satu mata kuliah penciri jurusan. Filsafat Bahasa bukan hanya mengkaji bahasa sebagai kajian filsafat, tetapi juga hubungan bahasa dengan filsafat. Bahasa yang dimaksud bukan hanya bahasa secara umum, tetapi juga bahasa Indonesia. Merujuk pada RPS, mata kuliah ini dapat dikelompokkan pada mata kuliah teori. Oleh karena itu, perkuliahan lebih banyak melakukan aktivitas belajar teori. Pembelajaran pada mata kuliah ini dilakukan dengan diskusi dan tanya jawab. Dosen membagi kelas menjadi beberapa kelompok. Setiap kelompok diminta untuk membuat makalah. Tema makalah ditentukan oleh dosen. Penentuan ini berdasarkan pada sebaran materi yang terdapat pada RPS. Makalah tersebut lalu dipresentasikan. Setelah itu, dosen memberi kesempatan kepada mahasiswa lain untuk mengajukan pertanyaan.

Teori Belajar Bahasa. Membaca namanya, mata kuliah ini jelas sekali masuk dalam kategori mata kukliah teori. Mata kuliah ini merupakan mata kuliah penciri jurusan. Meskipun menggunakan nama teori, mata kuliah ini memiliki tujuan agar mahasiswa dapat menerapkan berbagai teori belajar bahasa sesuai situasi dan kondisi. Artinya, selain belajar tentang teori, mahasiswa juga diminta untuk mempraktikkan teori tersebut. Pembelajaran pada mata kuliah ini menggunakan penugasan dan penelitian mini. Penugasan dilakukan secara kelompok sedangkan penelitian dilakukan secara individu. Penugasan kelompok berupa pembuatan makalah. Dosen membagi mahasiswa menjadi beberapa kelompok. Setiap kelompok terdiri atas tiga mahasiswa. Setiap kelompok diminta untuk membuat makalah. Materi makalah ditentukan oleh dosen.

Setiap pertemuan terdapat tiga kelompok yang presentasi. Sesi tanya jawab hanya diberikan kesempatan kepada tiga penanya. Makalah yang dibuat harus menggunakan referensi dari jurnal, baik berbahasa Indonesia maupun Inggris. Makalah yang dibuat menggunakan format artikel ilmiah. Lengkap dengan abstrak. Setiap mahasiswa dapat belajar dari makalah dan presentasi yang dilakukan. Sebelum mata kuliah berakhir, dosen akan menjelaskan kembali materi yang dipresentasikan oleh mahasiswa. Dosen 
juga akan mengulas berbagai pertanyaan yang diajukan, terutama yang belum dijawab dengan tepat.

Setelah mahasiswa merasa cukup dengan ilmu yang diperoleh, dosen kembali memberi tugas. Tugas ini berupa tugas individu. Setiap mahasiswa diminta untuk mengamati pemerolehan dan pembelajaran bahasa yang terjadi. Mahasiswa boleh menentukan lokasi dan objek sesuai keinginan. Setelah mengamati, mahasiswa diminta menentukan teori yang digunakan pada kegiatan pembelajaran bahasa tersebut. Teori dapat diperoleh dari tugas kelompok. Pada tugas individu ini, mahasiswa memiliki waktu dua minggu untuk mengamati dan dua minggu untuk menulis hasil pengamatan itu dalam bentuk artikel ilmiah dan catatan lapangan.

Diharapkan melalui tugas ini, mahasiswa dapat mengetahui berbagai teori belajar bahasa. Selain itu, mahasiswa dapat menerapkan teori tersebut berdasarkan ciri-cirinya. Hal yang tidak kalah penting, mahasiswa belajar melakukan penelitian dan menulis ilmiah. Mahasiswa belajar memperoleh dan mengumpulkan data. Mahasiswa juga belajar menganalisis data. Bahkan, artikel yang diangap baik dapat dipublikasikan di jurnal Jurusan Tadris Bahasa Indonesia. Artinya, mahasiswa dapat memperoleh banyak keuntungan dari tugas mata kuliah ini. Jika artikelnya dimuat di jurnal, maka mahasiswa tersebut dapat mengajukan dan memperoleh SKPI (Surat Keterangan Pendamping Ijazah).

Membaca. Membaca merupakan mata kuliah praktik. Sebagai mata kuliah penciri jurusan, membaca mengharuskan mahasiswa tidak hanya memiliki kemampuan dalam hal teori, tetapi juga dalam hal praktik. Di RPS tertulis bahwa mata kuliah ini bertujuan agar mahasiswa memiliki keterampilan membaca, baik bersuara maupun tidak. Selain itu, mahasiswa juga memiliki kemampuan membaca, baik indah maupun resmi. Pembelajaran pada mata kuliah ini lebih banyak melakukan praktik. Pada pertemuan pertama dan kedua, dosen menyampaikan materi. Pada pertemuan berikutnya, dosen meminta mahasiswa praktik membaca. Selanjutnya, dosen akan mengulas dan menunjukkan berbagai aspek yang dilakukan mahasiswa ketika membaca tadi. Hal ini secara tidak langsung dapat memberi mahasiswa berbagai teori tentang membaca.

Secara umum, pembelajaran yang dilakukan di Jurusan Tadris Bahasa Indonesia relatif sama. Perbedaan ditemukan pada mata kuliah praktik atau keterampilan. Sebagai mata kuliah praktik, sudah sangat wajar jika mahasiswa lebih banyak melakukan praktik 
atau melakukan sesuatu. Namun demikian, praktik ini belum berorientasi pada individu. Artinya, praktik masih dilakukan secara kelompok. Hal ini terjadi karena keterbatasan waktu dan jumlah mahasiswa yang berlebih.

Hendaknya pada mata kuliah praktik, jumlah mahasiswa maksimal 20. Hal ini untuk memaksimalkan evaluasi terhadap penguasaan yang dimiliki mahasiswa. Artinya, kemajuan pembelajaran setiap mahasiswa dapat terpantau oleh dosen. Seperti telah diketahui bersama bahwa keterampilan tidak dapat dilihat secara berkelompok. Keterampilan merupakan hal yang harus dimiliki setiap individu. Oleh karena itu, jika jumlah mahasiswa terlalu banyak, dosen tidak dapat secara maksimal dalam menumbuhkan dan mengembangkan keterampilan setiap mahasiswa.

Demi menunjang mata kuliah praktik, sudah saatnya jika Jurusan Tadris Bahasa Indonesia memiliki laboratorium. Tempat seperti ini sangat penting untuk memaksimalkan pembentukan keterampilan mahasiswa. Laboratorium yang dimaksud dapat berupa tempat khusus dalam bentuk ruangan, tetapi juga dapat berupa sekolahan. Walau pun sebenarnya, dosen dapat kreatif dan inovatif dalam menentukan media pembelajaran. Artinya, dosen sebenarnya dapat leluasa dan memanfaatkan segala yang ada di sekitar mahasiswa sebagai sarana dalam belajar.

Meskipun mata kuliah praktik, tentu saja mahasiswa juga harus memiliki teori dasar. Teori dasar ini selain diperoleh dari buku, sebenarnya juga dapat berasal dari hasil penelitian. Sekian mata kuliah hanya satu yang menggunakan hasil penelitian dalam bentuk artikel ilmiah sebagai bahan pembelajaran. Hal ini perlu lebih disosialisasikan dan dimaksimalkan sehingga dosen dan mahasiswa terbiasa dengan aktivitas ilmiah.

Demikian pun dengan mata kuliah teori. Mata kuliah ini tidak seharusnya melulu berupa ceramah atau diskusi. Hal ini karena teori dalam ilmu sosial selalu mengalami perkembangan. Oleh karena itu, dosen diharapkan selalu mengikuti perkembangan berbagai teori yang ada. Hal ini dapat dilakukan dengan mempelajari hasil penelitian yang dilakukan orang lain. Artinya, sangat mungkin dosen bersama-sama dengan mahasiswa membaca, mempelajari, dan mengambil manfaat dari hasil penelitian yang dilakukan oleh orang lain. Sehingga meskipun teori, mata kuliah ini hendaknya memiliki kebaruan dan selalu melibatkan mahasiswa. 


\section{Journal Indonesian Language Education and Literature Vol. 2, No. 2, 2017 \\ http://www.syekhnurjati.ac.id/jurnal/index.php/jeill/}

Dosen dan mahasiswa merupakan orang-orang akademis. Salah satu ciri keakademis-an terletak pada kemampuan dalam menyampaikan, baik secara lisan maupun tulis. Akademis selalu diidentikkan dengan ilmiah. Oleh karena itu, dosen dan mahasiswa hendaknya selalu berpikir ilmiah. Berpikir ilmiah dapat melalui tulisan maupun perkataan. Berpikir ilmiah melalui tulisan diwujudkan pada artikel dan dipublikasikan di sebuah jurnal.

Banyak manfaat yang dapat diperoleh jika dosen dan mahasiswa memanfaatkan hasil penelitian, terutama yang sudah berbentuk artikel dan dijurnalkan. Secara garis besar, terdapat dua hal yang dapat diperoleh, yakni materi dan metodologi penelitian. Dari segi materi: dosen dan mahasiswa dapat memperoleh materi terbaru. Materi tersebut dapat berupa teori-teori serta penerapannya yang terbaru. Hal ini karena materi dalam ilmu sosial dan humaniora selalu mengalami perkembangan. Perkembanganperkembangan ini sangat penting untuk diketahui. Penelitian pada dasarnya adalah penerapan dari sebuah teori. Hasil penerapan teori ini mungkin dan pasti berbeda-beda. Hal ini sangat dapat diterima. Oleh karena itu, jika dosen dan mahasiswa banyak memanfaatkan hasil penelitian berupa artikel, tentu saja dapat menambah wawasan.

Dari metodologi penelitian: dosen dan mahasiswa sedikit demi sedikit mulai belajar cara meneliti dan menuliskan hasil penelitian. Setidaknya dengan belajar dari artikel, dosen dan mahasiswa dapat mengetahui berbagai metode penelitian yang digunakan. Dosen dan mahasiswa juga dapat belajar cara menulis ilmiah, terutama untuk menulis artikel.

Satu hal lagi yang perlu diperhatikan pada setiap pembelajaran adalah produk akhir. Alangkah lebih baik jika mahasiswa memiliki produk akhir pada setiap mata kuliah. Apa pun bentuk produk itu diharapkan dapat menjadi salah satu bukti pemahaman mahasiswa terhadap mata kuliah yang bersangkutan. Harapannya adalah bahwa pada setiap mata kuliah tidak hanya mengajarkan sesuatu, tetapi juga menerapkan dan membuktikan apa yang telah dipelajari. Apalagi jika sesuatu yang dihasilkan itu sangat berguna bagi kehidupan, terutama pembelajaran selanjutnya.

Proses lengkapnya sebagai berikut. Kelompok yang mendapat giliran presentasi menyampaikan isi makalah yang sudah dibuat. Selesai presentasi dilanjutkan dengan tanya jawab seputar materi yang didiskusikan. Pada sesi ini, mahasiswa lain diperbolehkan untuk menanggapi, baik berupa sanggahan, pertanyaan, maupun 
pernyataan. Berbagai tanggapan yang disampaikan oleh peserta diskusi, ditanggapi pula oleh pemakalah. Setelah dirasa cukup, sesi diskusi pun ditutup. Setelah itu, dosen menambah penjelasan terkait berbagai pertanyaan yang disampaikan oleh peserta diskusi. Lalu dosen menutup perkuliahan. Begitulah rutinitas perkuliahan yang dilakukan di Jurusan TBI IAIN Syekh Nurjati Cirebon.

Berdasarkan pengamatan yang telah dilakukan dapat disimpulkan bahwa di antara 11 mata kuliah, hanya satu mata kuliah yang memanfaatkan riset atau hasil penelitian sebagai bahan pembelajaran. Mata kuliah tersebut adalah Teori Belajar Bahasa. Pada mata kuliah ini mengkaji berbagai hasil penelitian yang menerapkan teori belajar bahasa, baik bahasa pertama maupun kedua. Adapun metode belajarnya adalah dengan membagi kelas ke dalam beberapa kelompok. Setiap kelompok terdiri atas 5-6 mahasiswa. Setiap kelompok diminta mencari sebuah artikel yang membahas penerapan teori belajar bahasa. Setiap kelompok juga diminta mempresentasikan isi artikel. Aktivitas belajar dilanjutkan dengan tanya jawab. Dosen bertugas menjelaskan ulang berbagai jawaban yang belum jelas serta menjelaskan ulang berbagai jawaban yang belum tepat.

Pada kesempatan berikutnya, dosen mengulas artikel yang baru didiskusikan. Pembahasan yang dilakukan dosen tidak sebatas pada isi artikel, tetapi juga meluas pada hal lain. Hal pertama yang dilakukan dosen adalah meminta mahasiswa untuk mencermati judul artikel. Mahasiswa diminta untuk menjelaskan kembali dengan bahasa sendiri, maksud dari judul artikel tersebut. Dosen meminta mahasiswa menyebutkan komponen atau aspek yang terdapat pada judul artikel. Setelah itu, dosen meminta mahasiswa mencermati bagian latar belakang dari artikel tersebut. Mahasiswa diminta menjelaskan kembali latar belakang yang ada dalam artikel dengan bahasa sendiri. Dosen mengaitkan latar belakang tersebut dengan berbagai kasus yang ada di sekitar.

Selanjutnya, dosen meminta mahasiswa mencermati bagian rumusan masalah. Mahasiswa diminta untuk menjelaskan keterkaitan rumusan masalah dengan latar belakang. Dosen meminta mahasiswa untuk mencatat rumusan masalah pada artikel tersebut. Dilanjutkan pada bagian teori. Mahasiswa diminta mencermati berbagai teori yang ada di artikel. Dosen menunjuk 2-3 mahasiswa untuk menjelaskan teori yang digunakan dengan menggunakan bahasa sendiri. Seorang mahasiswa diminta untuk 
menyusun sintesis dari berbagai teori yang digunakan. Dosen meminta mahasiswa lain untuk menjelaskan keterkaitan teori $\rightarrow$ rumusan masalah $\rightarrow$ latar belakang $\rightarrow$ judul. Hal ini agar mahasiswa mengetahui peran teori dalam sebuah penelitian.

Bagian selanjutnya adalah metode penelitian. Pada kesempatan ini, dosen mengajukan beberapa pertanyaan dan mahasiswa diminta untuk menjawab. Pertanyaan berkisar pada hal-hal yang ada pada metode penelitian. Mahasiswa diharapkan dapat mempelajari dan memetakan hal-hal yang harus ada pada metode penelitian, misalnya: cara menentukan informan atau sampel, cara memperoleh atau mengumpulkan data, cara mengetahui atau mengecek keakuratan dan kevalidan data, serta cara menganalisis data. Semakin sering mempelajari hal tersebut, mahasiswa akan menjadi terbiasa dan tidak bingung ketika menghadapi masalah yang sama.

Masuk pada bagian pembahasan. Dosen meminta mahasiswa membaca kembali rumusan masalah yang sudah dicatat. Salah satu dari mahasiswa yang presentasi diminta untuk menjawab rumusan masalah. Jawaban tersebut berasal dari bagian pembahasan di artikel, tetapi disampaikan ulang dengan bahasa sendiri. Anggota kelompok yang presentasi diminta untuk membantu memberi penjelasan. Demi meyakinkan pemahaman seluruh mahasiswa, dosen mengulangi uraian kelompok yang presentasi serta memberi penjelasan-penjelasan tambahan.

Banyak manfaat yang diperoleh melalui pembelajaran berbasis riset ini. Pertama, dosen dipaksa untuk belajar hal-hal yang terkait dengan artikel yang dipresentasikan. Hal ini karena tentu saja masalah yang dibahas memiliki keterkaitan dengan ilmu-ilmu lain. Oleh karena itu, dosen dituntut untuk dapat mengaitkan berbagai pengetahuan sehingga dapat menguraikan penyelesaian seperti pada artikel.

Kedua, mahasiswa tidak hanya belajar teori. Selain mempelajari teori yang ada pada artikel, mahasiswa juga dapat mempelajari penerapan teori tersebut. Melalui artikel ini, mahasiswa belajar menyelesaikan masalah dengan berbagai teori tanpa harus terjun langsung ke lapangan. Dalam hal ini, mahasiswa tidak memerlukan waktu banyak untuk belajar teori. Mahasiswa dapat belajar teori dan mempraktikkannya secara bersamaan. Dalam waktu yang tidak lama, mahasiswa dapat mengetahui penerapan berbagai teori serta dapat menyelesaikan berbagai masalah.

Ketiga, mahasiswa tidak hanya belajar tentang ke-ilmuan, tetapi juga belajar tentang penelitian. Melalui artikel tersebut, mahasiswa dapat belajar tentang metodologi 


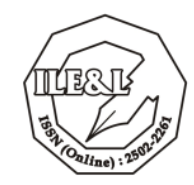

Journal Indonesian Language Education and Literature Vol. 2, No. 2, 2017

http://www.syekhnurjati.ac.id/jurnal/index.php/jeill/

penelitian. Selain itu, mahasiswa juga dapat mempelajari kaidah penulisan sebuah artikel ilmiah, baik format, sistem rujukan, cara menuliskan kutipan, maupun bahasa yang digunakan.

\section{Simpulan}

Berdasarkan analisis di atas dapat disimpulkan bahwa: 1) pembelajaran di Jurusan Tadris Bahasa Indonesia IAIN Syekh Nurjati menggunakan berbagai metode. Secara umum menggunakan ceramah dan diskusi; 2) model pembelajaran berbasis riset yang digunakan di Jurusan Tadris Bahasa Indonesia IAIN Syekh Nurjati belum maksimal. Hal ini terlihat dari 11 mata kuliah, hanya satu mata kuliah yang menggunakan artikel sebagai referensi; dan 3) mahasiswa merasa bosan dengan model pembelajaran yang digunakan di Jurusan Tadris Bahasa Indonesia IAIN Syekh Nurjati. Kebosanan ini karena setiap dosen menerapkan model yang sama, yakni membagi mahasiswa menjadi beberapa kelompok. Setiap kelompok diminta untuk membuat makalah lalu mempresentasikan.

\section{Daftar Pustaka}

Bellanca, J. 2011. 200+ Strategi dan Proyek Pembelajaran Aktif untuk Melibatkan Kecerdasan Siswa (Edisi Kedua). Jakarta: Indeks.

Cohen, Louis, et al. 2000. Research Methods in Education. Great Britain: TJ International Ltd, Padstow, Cornwall.

Henard, F. \& Deborah, Roseveare. 2012. Fostering Quality Teaching in Higher Education: Policies and Practices. Perancis: IMHE.

Joyce, B., Weil, M., \& Calhoun, E. 2011. Model-model Pengajaran. Yogyakarta: Pustaka Pelajar.

Moleong, Lexy. J. 2000. Metode Penelitian Kualitatif. Bandung: Remaja Rosdakarya.

. 2010. Metode Penelitian Kualitatif. Edisi Revisi. Bandung: Remaja Rosdakarya.

Sukmadinata, N. S. \& Syaodih, E. 2012. Kurikulum dan Pembelajaran Kompetensi. Bandung: Refika Aditama.

Supriadie, D. \& Darmawan, D. 2012. Komunikasi Pembelajaran. Bandung: Rosda. 


\section{Journal Indonesian Language Education and Literature Vol. 2, No. 2, 2017 \\ http://www.syekhnurjati.ac.id/jurnal/index.php/jeill/}

Suwandi, Sarwiji. 2008. Semantik: Pengantar Kajian Makna. Yogyakarta: Media Perkasa.

Tarigan, Henry Guntur. 2009. Pengajaran Sintaksis. Bandung: Angkasa.

Umar, Masri Kudrat dkk. 2011. Pengembangan Pembelajaran Berbasis Riset di Program Studi Pendidikan Fisika FMIPA Universitas Negeri Gorontalo. http://repository.ung.ac.id/riset/show/2/802/pengembangan-pembelajaranberbasis-riset-di-program-studi-pendidikan-fisika-fmipa-universitas-negerigorontalo-ketua.html diunduh Senin, 28 Maret 2016 pukul 10.30 WIB.

Verhaar, J.W.M. 2012. Asas-asas Linguistik Umum. Yogyakarta: Gadjah Mada University Press.

Wahyuni, S. \& Ibrahim, A.S. 2012. Perencanaan Pembelajaran Bahasa Berkarakter. Bandung: Refika Aditama.

Widayati Dkk. 2010. Pedoman Umum Pembelajaran Berbasis Riset (PUPBR). Universitas Gadjah Mada.

Yule, George. 2014. Kajian Bahasa. Yogyakarta: Pustaka Pelajar. 